commission is determined by a separate special law, there is also the problem of uncertainty about the legal status of such a commission. According to the current legislation, the legal basis for the activities of the national commission in the field of transport as a central executive body must be determined in accordance with the legislation on central executive bodies, namely: at the level of the relevant regulation approved by the Cabinet of Ministers.

Key words: port dues; national commission for state regulation in the field of transport; control over the targeted use of funds from port dues.

DOI: $10.36695 / 2219-5521.4 .2020 .33$

УДК $346.1 / 9$

\title{
Є.Ю. БОСЕНКО
}

Євгеній Юрійович Босенко, начальник управління Державної аудиторської служби України, аспірант Київського національного торгівельно-економічного університету*

ORCID: 0000-0002-0792-8456

\section{ПРАВОВИЙ СТАТУС САМОРЕГУЛІВНИХ ОРГАНІЗАЦІЙ ОЦІНЮВАЧІВ}

Постановка проблеми. Становлення та розвиток України як демократичної, соціальної та правової держави неможливе без ефективного саморегулювання професійної діяльності, яке має забезпечити гармонійний розвиток держави у напрямі належної взаємодії між громадянським суспільством та органами державної влади. Офіційно визнано в Україні лише вісім саморегулівних організацій (далі - СРО) з оціночної діяльності, в тому числі з оцінки земель, дві - із землеустрою. Разом із тим в окремих видах оціночної діяльності існують організації, що за сукупністю виконуваних ними функцій та за властивими їм ознаками можуть бути віднесені до саморегулівних, але законодавством не передбачено можливості саморегулювання у відповідних сферах. Водночас у законодавстві немає єдиного підходу до визначення правового статусу саморегулівних організацій в оціночній діяльності, відсутній системний і комплексний порядок утворення та діяльності саморегулівних організацій.

Питання саморегулювання останнім часом досить активно обговорюється в наукових колах. Учені намагаються створити концепції саморегулювання, виходячи з позиції теорії права, адміністративного, цивільного, господарського права та інших галузей. Однак комплексного дослідження становища саморегулівних організацій професійної оціночної діяльності не здійснено. Такий погляд не сприяє повноцінному розкриттю сутності та змісту саморегулювання професійної діяльності.

Аналіз останніх досліджень і публікацій. Проблемні аспекти дослідження сучасної правової доктрини саморегулювання професійної діяльності відображені в роботах вітчизняних та зарубіжних учених, зокрема: М. Айснера, О. Бакалінської, Л. Баккаро, А. Бобкової, О. Беляневич, О. Вінник, О. Гончаренко, С. Демченка, В. Добровольської, Д. Задихайла, О. Кологойди, В. Кочина, Т. Кравцової, А. Науменка, Е. Огуса, Н. Філатової, Д. Фішера, Дж. Шорта, В. Щербини та ін. Питання саморегулювання досліджувалося здебільшого в розрізі діяльності певних саморегулівних організацій, їх правового статусу та функцій, взаємодії 3 органами державної влади, окремих засобів саморегулювання.

Гіпотеза - правова регламентація оціночної діяльності в Україні є недосконалою, вимагає внесення певних коректив, тому на підставі аналізу європейського законодавства про оціночну діяльність необхідно визначити недоліки правових основ регулювання оціночної діяльності в Україні і запропонувати варіанти їх усунення.

Формулювання мети статті. Метою статті є визначення особливостей правового статусу саморегулівних організацій оцінювачів в Україні на підставі дослідження положень національного законодавства, іноземних держав; розробка пропозицій з удосконалення законодавства України з питань саморегулювання.

Виклад основного матеріалу. Інститут оціночної діяльності в європейських державах $€$ досить розвиненою сукупністю некомерційних, саморегулівних організацій, що здійснюють оціночну діяльність в різних аспектах розвитку та функціонування суспільства. Під оціночною діяльністю розуміється діяльність незалежних некомерційних організацій (саморегулівних), прихильних підвищенню якості в професії оцінювача. Роль оціночної діяльності - зміцнення довіри суспільства до оцінки шляхом розробки стандартів і забезпечення їх універсального прийняття і впровадження для оцінки активів у всьому світі. На нашу думку, оціночна діяльність $є$ фундаментальною частиною фінансової системи, поряд із високим рівнем професіоналізму в їх застосуванні. Варто зауважити, що саморегулівні організації доволі незалежні у своїй діяльності. Втручання органів державної влади чи органів місцевого самоврядування, їх посадових та службових осіб

(C) Є.Ю. Босенко, 2020

* Yevhenii Bosenko, Head of the Department of the State Audit Service of Ukraine, Postgraduate student of Kyiv National Trade and Economic University of Ukraine

Часопис Київського університету права • 2020/4 
у роботу саморегулівних організацій небажане. Зрозуміло, що повноваження публічних органів влади та їх посадових осіб щодо контролю та нагляду за саморегулівними організаціями мають бути чітко сформульовані на рівні закону.

Головною метою створення саморегулівних організацій є контроль та впорядкування діяльності на певному ринку або в певній сфері, галузі, виді економічної діяльності, представлення й захист інтересів своїх учасників та створення відповідних норм, контроль за їх виконанням. Варто зауважити, що мета може бути пов'язана з виконанням певних публічних завдань.

Н.Ю. Філатова зазначає, що: «... мета утворення СРО полягає не просто у здійсненні «регулювання для регулювання», а в розробці додаткових правил, норм і підвищених стандартів діяльності для їх членів $i$ здійсненні контролю за їх дотриманням з метою задоволення інтересів широкого кола споживачів, з одного боку, а також забезпечення ділових інтересів членів СРО - з другого» 1 .

М. Олсон стверджує, що «... «сильні бізнес-асоціації» фактично завдають шкоди національній економіці, оскільки протистоять ринковій конкурениії; гальмують впровадження $i$ широке розповсюдження нових технологій...; протистоять ефективності та економічності, які є чинниками міжнародної торгів$\pi i \gg »^{2}$.

Різноманітність назв та підходів до визначення явища СРО підкреслюють недосконалість та прогалини законодавчого регулювання, неусталеність понятійного апарату та безсистемний підхід щодо належного правового забезпечення цього явища. СРО має діяти передусім у сфері економічної діяльності, а особливість iii функціонування має бути виокремлено із загального розуміння інших неприбуткових організацій. СРО $\epsilon$ учасницею цивільно-правових та господарсько-правових відносин, має колективні права інтелектуальної власності для забезпечення власної діяльності здійснювати господарську діяльність у встановлених законодавством межах.

Варто зазначити, що поняття саморегулівної організації закріплено на законодавчому рівні. Цікаво, що вперше визначення саморегулівної організації надавалося Законом України «Про державне регулювання ринку цінних паперів» від 30 жовтня 1996 р. № 448/96-ВР, у ст. 13. Згодом таке положення було виключено. Наразі на фондовому ринку саморегулівні організації діють відповідно до Закону України «Про цінні папери та фондовий ринок» від 23 лютого 2006 р. № 3480-IV, поняття СРО закріплено у: ч. 2 ст. 24. Дефініція СРО закріплена також у ст. 66 Закону України «Про інститути спільного інвестування» від 5 липня 2012 р. № 5080-VI5, п. 9 ч. 1 ст. 1 Закону України «Про фінансові послуги та державне регулювання ринків фінансових послуг» від 12 липня 2001 р. № 2664-III6, ст. 1 Закону України «Про недержавне пенсійне забезпечення» від 9 липня 2003 р. № 1057-IV7, ст. 26 Закону України «Про оцінку майна, майнових прав та професійну оціночну діяльність в Україні» від 12 липня.2001 p. ${ }^{8}$

О. Гончаренко стверджує, що саморегулівні організації в більшості випадків обов'язково залучаються до процесу формування державної політики на певному ринку, у сфері, галузі, виді господарської діяльності шляхом розроблення проєктів нормативно-правових актів9. Органи державної влади проводять різноманітні консультації з питань здійснення господарської або професійної діяльності, утворюють дорадчі та інші допоміжні органи, в роботі яких беруть участь представники саморегулівних організацій. Таким чином, саморегулівні організації залучаються до вирішення питань місцевого значення на рівні органів місцевого самоврядування. Тому цілком очевидно, що співпраця, здійснення нагляду та контролю з боку держави щодо саморегулівних організацій має бути максимально прозорою. На думку О. Гончаренко, саморегулівні організації $\epsilon$ певним вільним майданчиком для формування, усвідомлення та реалізації інтересів усіх заінтересованих осіб у регулюванні певного ринку, сфери, галузі чи виду господарської або професійної діяльності, то залучення цих організацій до розробки законопроєктів, проведення консультацій з ними 3 питання утворення, компетенції СРО, нагляду та контролю за їх діяльністю, розподілу функцій з нагляду та контролю між органами публічної влади та СРО є обов'язковим. Саме тому взаємодія та співпраця із саморегулівними організаціями на основі визначених законом норм є запорукою ефективного регулювання.

Діяльність саморегулівної організації оцінювачів закріплена в Законі України «Про оцінку майна, майнових прав та професійну оціночну діяльність в Україні» від 12 липня 2001 р. № 2658-III'10. Аналіз цього закону виявляє певні колізії. У сфері оцінки майна спочатку створюється громадська організація, якій може бути згодом надано вдруге офіційний статус СРО, тому законодавець і каже про громадський контроль. Але варто відзначити суттєвий нюанс: офіційно визнана СРО не може здійснювати громадське регулювання, оскільки є представником бізнесу і в багатьох випадках лобіює його інтереси і на цьому етапі стає стороною процесу регулювання. СРО не може здійснювати «громадський» контроль за своєю діяльністю. Саме тому доцільно вважати, що слід виключити положення в Законі України «Про оцінку майна, майнових прав та професійну оціночну діяльність в Україні» від 12 липня 2001 р. № 2658-III щодо громадського регулювання, яке здійснює саморегульована організація.

Звісно ж концептуально хибним є віднесення оціночної діяльності до публічно-значимих видів діяльності, що порушує деякі засадничі положення цивільного українського законодавства.

По-перше, регулювання оціночної діяльності, встановлене законом, суперечить правовій природі оціночної діяльності. Закон визначає оцінну діяльність як професійну, що не є підприємницькою. Разом із тим, з аналізу цивільного законодавства випливає, що за своєю цивільно-правовою природою оціночна діяльність $€$ саме підприємницькою. Оціночна діяльність не має публічного характеру, і це кардинально відрізняє їі від діяльності, наприклад, нотаріусів та арбітражних керуючих. У результаті сучасне регулювання оціночної 
діяльності прийшло в протиріччя з їі правовою природою, воно порушує положення цивільного законодавства про підприємницьку діяльність і не відповідає завданням та цілям реформи.

По-друге, закон поклав цивільно-правову відповідальність за результати оцінки на оцінювача - працівника юридичної особи, яка уклала договір на проведення оцінки, і фактично звільнив від такої відповідальності зазначену юридичну особу. Тим самим закон концептуально порушив імперативні положення цивільного законодавства про суб'єктів цивільного права, підстави виникнення їх прав і обов'язків, підстави та умови відповідальності за порушення зобов'язань.

Відповідно до зазначених положень саме юридична особа, що уклала договір на проведення оцінки, має нести відповідальність за невиконання або неналежне виконання прийнятих на себе зобов'язань. Таким чином, юридична особа, що уклала договір на проведення оцінки, і є повноправним суб'єктом оціночної діяльності.

З урахуванням посилення інтеграції України в європейський простір слід звернутися до питання оціночної діяльності з позиції європейського законодавства, зокрема, Бельгії та Польщі.

У даний час у Бельгії титул оцінювача («сюрвейера») закріплений за незалежним фахівцем зі спеціальною освітою, який відповідає нормативним вимогам для виконання необхідних професією завдань сертифікованого оцінювача.

«Сюрвейер» пропонує свої послуги в наступних сферах:

- у сфері шлюбно-сімейних відносин - для кваліфікаційної оцінки нотаріальних документів, поданих у випадках: правонаступництва, обміну, розділу, підрахунку часткою в нерухоме майно, в спірних питаннях;

- в будівельній галузі - для виконання технічних замірів, вимірювань, консультації тощо;

- в економічній сфері - для проведення оцінки продуктів фінансової сфери.

Завдання оцінювача повинні відповідати таким умовам (стандартам якості):

- незалежність: оцінювач - це вільна професія. Немає комерційних цілей, які могли б суперечити професійній діяльності оцінювача; він також повинен бути зареєстрований у Реєстрі оцінювачів. На даний момент не існує органу, в який клієнт міг би подати скаргу на передбачувані помилки в роботі оцінювача. Якщо оцінювачі належать до профспілок, клієнт може подати скаргу в профспілки. Кваліфікація оцінювача повинна бути підтверджена документально (дипломами про вищу професійну освіту; дипломами про проходження курсів підвищення кваліфікації і т.д.). Однак сьогодні в бельгійському законодавстві існує «пробіл», який дав можливість групі осіб-оцінювачів займатися професійною оціночною діяльністю без необхідної освіти. Новий закон покликаний запобігти зловживанням подібного роду.

Варто зазначити, що в Бельгії найбільш розвинена і затребувана професія оцінювача нерухомості до завершення продажу або рефінансування власності. Кредитори зазвичай покладаються на незалежних оцінювачів нерухомості, оскільки нерухомість є запорукою для позики, яка використовується для фінансування угоди. Кредитор може заарештувати і продати нерухомість в разі невиконання позичальником своїх зобов'язань. Позичальники, які купують або рефінансують нерухомість, також можуть зажадати проведення оцінки, щоб переконатися в тому, що ціна власності відповідає об'єктивній оцінці їі вартості.

Поточне регулювання оцінки власності засновано на законодавстві, прийнятому після двох фінансових криз: законодавство, що регулює оцінку, включає Розділ ХІ Закону 1989 р. про реформу, відновленні й правозастосуванні фінансових інститутів (FIRREA, PL 101-73)11, а також Закон Додда-Франка про реформу Уолл-стріт і захисту прав споживачів (Закон Додда-Франка, PL 111-203), який вступив в силу після Subprime Mortgage. На додаток до змін, внесених до Закону Додда-Франка, вимоги про незалежність оцінювача були включені в Закон про житлове будівництво і економічному відновленні (HERA) від 2008 р.

Як наглядовий орган за ліцензуванням та сертифікацією оцінювачів нерухомості був створений Підкомітет з оцінкою (ASC) в рамках екзаменаційного ради федеральних фінансових установ (FFIEC) $)^{12}$, але ліцензування і сертифікація оцінювачів було залишено на розсуд державних органів.

Згідно $з$ польським законодавством, оцінювач - це особа, яка має державну ліцензію на оцінку нерухомості. Варто звернути увагу, що в польському, так само як і в бельгійському суспільстві, превалює оціночна діяльність нерухомості. Ліцензію можна отримати, здавши іспит у Державній екзаменаційній комісії. Для складання іспиту необхідно мати академічну освіту в галузі права чи економіки. Крім того, якщо освіта кандидата не відповідає вимогам програми, він або вона повинні закінчити аспірантуру за обраним напрямом.

Шлях до отримання ліцензії докладно описаний у стандартах PFSRM (Польська федерація асоціацій оцінювачів):

1. Визначення оцінювача.

1.1. Оцінювач - це фізична особа, яка має дозвіл на оцінку нерухомості, видане Міністерством інфраструктури або президентом Інституту територіального управління та житлового будівництва відповідно до закону про геодезії і картографії від 17 травня 1989 р., а також президентом Інституту територіального управління та житлового будівництва відповідно до закону про управління нерухомістю від 21 серпня $1997 \mathrm{p}$.

1.2. Виконання роботи оцінювача без необхідного дозволу заборонено під загрозою застосування санкцій у вигляді грошового штрафу, встановленого Законом про управління нерухомістю.

1.3. Оцінювач отримує ліцензію на виконання своїх завдань в день реєстрації в Реєстрі оцінювачів, який веде Інститут територіального управління та житлового будівництва. Витяги з Реєстру, що стосуються оцінювачів, публікуються губернаторами провінцій в місцевих офісних журналах. 
Як видно з наведеного вище порівняння, отримання титулу оцінювача в Польщі регулюється дуже точними і суворими правилами, на відміну від бельгійського законодавства. Практично необхідно закінчити аспірантуру і здати державний іспит високого рівня складності. У Бельгії отримати подібний дозвіл набагато простіше. Насправді досить мати відповідний диплом про професійну вищу освіту. Також можливо без значних перешкод провести нострифікацію ліцензій, отриманих в інших європейських країнах ЄС. Для цього достатньо двох років практики. Це приводить до висновку, що найбільш важливим фактором є регульований ринок оцінювачів, здатний істотно впливати на якість проведених оцінок.

Немає принципових відмінностей між професійною кваліфікацією і обов'язками оцінювачів у Польщі і Бельгії. Але в Польщі існує тенденція до інституціонального регулювання речей, особливо щодо способів отримання ліцензії і питань професійної відповідальності, у той час як у Бельгії точно більше свободи дій i більш легкий доступ до ведення професійної діяльності. Також добре видно різницю в тривалості навчання. У Бельгії досить закінчити трирічний бакалаврат, у той час як у Польщі навчання даної професії триває п'ять років з обов'язковою післядипломною практикою.

Обов'язки бельгійського оцінювача набагато «скромніше», але це не означає, що він не несе відповідальності - в основному фінансової - за допущені помилки. Розгляд бельгійського підходу до роботи оцінювача може показати деякі можливості наступності в професійній діяльності оцінювача в Польщі.

Аналіз чинного законодавства України в галузі саморегулювання свідчить про те, що на рівні законів не достатньо нормативно забезпечено здійснення нагляду та контролю за діяльністю СРО. Існуючі нечисленні підзаконні нормативно-правові акти, які прийнято в розвиток законів, лише поверхово передбачають проведення нагляду та контролю за діяльністю СРО і тільки в разі наявності офіційних СРО на певному ринку, сфері, галузі, виді господарської діяльності. Здебільшого в нормативних положеннях виконання функції нагляду та контролю за СРО полягає в повноваженнях публічних органів влади здійснювати перевірку щодо відповідності вимог законодавства України щодо набуття та втрати статусу СРО. Перевірці підлягає, першочергово, достовірність наданої інформації та своєчасність ії подання. У низці випадків до компетенції органів публічної влади входить контроль виконання повноважень з регулювання СРО господарської діяльності на ринку, сфері, галузі, виді господарської діяльності.

Висновок. На підставі всього сказаного можемо зробити висновок, що аналіз чинного законодавства у сфері саморегулювання свідчить про те, що на рівні законів України недостатньо нормативно регламентована діяльність оцінювачів. Нечисленні підзаконні нормативно-правові акти, які прийнято в розвиток законів, тільки поверхово регламентують діяльність саморегулівних організацій оцінювачів. Суттєвим недоліком законодавства України $\epsilon$ відсутність механізмів підтримки діяльності СРО, а тому з метою реального впровадження саморегулювання на початковому етапі потрібно створити нормативне забезпечення їх діяльності, де передбачити низку таких заходів. Необхідним залишається прийняття положень щодо прозорого й відкритого механізму проведення нагляду та контролю органами публічної влади.

Таким чином, автором дослідження доведено, що питання правового статусу саморегулівних організацій оцінювачів законодавством чітко не визначено і вимагає подальшої обробки.

Було проаналізовано зарубіжне законодавство, яке регламентує діяльність оцінювачів, що показало істотні відмінності в даній сфері діяльності. Це дає підставу вважати, що питання визначення правового статусу та забезпечення належного правового поля для саморегулівних організацій оцінювачів $\epsilon$ визначальним для успішного розвитку української держави.

1 Філатова Н. Поняття та ознаки саморегулівних організацій. Вісник Академії правових наук України. 2013. № 1. С. $280-290$.

2 Olson M. Power and Prosperity: Outgrowing Communist and Capitalist Dictatorships. New York. Basic Books, 2000.

3 Про державне регулювання ринку цінних паперів в Україні: Закон України від 30 жовтня 1996 р. № 448/96-ВР. Biдомості Верховної Ради України. 1996. № 51. Ст. 292.

4 Про цінні папери та фондовий ринок: Закон України від 23 лютого 2006 р. № 3480-IV. Відомості Верховної Ради України. 2006. № 31. Ст. 268.

5 Про інститути спільного інвестування: Закон України від 05 липня 2012 р. № 5080-VI.

6 Про фінансові послуги та державне регулювання ринків фінансових послуг: Закон України від 12 липня 2001 р. № 2664-III. Відомості Верховної Ради Украӥни. 2002. № 1. Ст. 1.

7 Про недержавне пенсійне забезпечення: Закон України від 09 липня 2003 р. № 1057-IV.

8 Про оцінку майна, майнових прав та професійну оціночну діяльність в Україні: Закон України від 12 липня 2001 р. № 2658-III. Відомості Верховної Ради України. 2001. № 47. Ст. 251.

9 Гончаренко О.М. Саморегулівні організації: проблематика делегування повноважень, нагляду та контролю. Приватне право і підприємниитво. 2019. Вип. 19. С. 156-163.

10 Кочин В.В. Цивільно-правові відносини участі суб'єктів підприємництва у саморегулівних організаціях : монографія. Київ : НДІ приватного права і підприємництва імені академіка Ф.Г. Бурчака НАПрН України, 2015. 128 с.

11 H.R. 1278, P.L. 101-73, became law August 9, 1989. The appraisal subcommittee of the FFIEC can be found at 12 U.S.C. 3301 et. seq.

12 The FFIEC includes the Federal Reserve Board (FRB), the Office of the Comptroller of the Currency (OCC), the Federal Deposit Insurance Corporation (FDIC), and the National Credit Union Administration (NCUA). 


\section{Резюме}

\section{Босенко С.Ю. Правовий статус саморегулівних організацій оцінювачів.}

У статті представлено питання наукових підходів дослідження правового статусу саморегулівних організацій оцінювачів; генеза становлення та розвитку законодавства щодо саморегулювання професійної оціночної діяльності. Проведений автором аналіз європейського законодавства в галузі забезпечення оціночної діяльності показав, що найбільш ефективні важелі управління закладені бельгійським законодавством, при цьому воно має істотні відмінності. Українське законодавство в питаннях визначення оціночної діяльності пропонує покласти весь функціонал в даній сфері на саморегульовані організації. Однак на сьогоднішній день з огляду на досить велику кількість колізійних норм українське законодавство так і не прийшло до єдності визначення та організації оціночної діяльності. За аналогією з європейським законодавством автором запропоновано поправки в чинне законодавство України.

Ключові слова: саморегулювання, саморегулівні організації (СРО), оцінка земель, землевпорядкування, публічне право, приватне право, оцінювальна діяльність.

\section{Резюме}

\section{Босенко Е.Ю. Правовой статус саморегулируемых организаций оценщиков.}

В статье представлены вопросы научных подходов исследования правового статуса саморегулируемых организаций оценщиков; генеза становления и развития законодательства о саморегулировании профессиональной оценочной деятельности. Проведенный автором анализ европейского законодательства в области обеспечения оценочной деятельности показал, что наиболее эффективные рычаги управления заложены бельгийским законодательством, при этом оно имеет существенные отличия. Украинское законодательство в вопросах определения оценочной деятельности предлагает возложить весь функционал в данной сфере на саморегулируемые организации. Однако на сегодняшний день ввиду достаточно большого количества коллизионных норм украинское законодательство так и не пришло к единству определения и организации оценочной деятельности. По аналогии с европейским законодательством автором предложены поправки в действующее законодательство Украины.

Ключевые слова: саморегулирование, саморегулируемые организации (СРО), оценка земель, землеустройство, публичное право, частное право, оценочная деятельность.

\section{Summary}

Yevhenii Bosenko. Legal status of Self-Regulating Organizations of Appraisals.

The aim of this article is to represent the state of the evolution and forming of the concept and determination of the legal status for self-regulatory organizations of appraisers in the independent state of Ukraine along with types of self-regulatory organizations of appraisers (the attempt of their classification is planned to be represented in the article, as well as the research of the issue on determination of the concept "professional activities" will be developed).

The process of establishment of Ukraine as democratic, social and legal state is hard to imagine without the availability of selfregulation of professional activities which will enable a harmonic development of the state towards proper interaction between the democratic society and state power authorities.

Such feature as activities of professional appraisers within the concept of legal status of self-regulatory organizations of appraisers has been particularly emphasized. As the number of researches concerning legal status of self-regulatory organizations of appraisers is very limited all over the world and, in Ukraine such scientific works dedicated to self-regulatory organizations specialized in appraisal professional activities are hardly ever met.

Nowadays only eight self-regulatory appraisal organizations have been officially recognized in Ukraine, including those which make land evaluation, and two of them are in the sphere of the organization of the use of land (Land Management).

Except of this, within the framework of several types of appraising activities such organizations exist as those which on the basis of complex of their performing functions, as well as close features to them can be considered as belonging to self-regulating ones, but legislation doesn't envisage possibilities for regulation in corresponding professional spheres.

At the same time, the national legislation lacks the unified approaches to the determination of the legal status of self-regulatory organizations (SRO), along with the system and complex procedure for the establishment of self-regulating organizations.

First, we present evidence and implications from an analysis of the domestic legislation in the field of administrative, civil, economic Law that till now any complex research on professional appraisal activities of self-regulation organizations has not been performed.

Second, we will present the event study results suggesting the essence and contents of self-regulation within appraisal activities.

Finally, we will find out that the problem issues of self-regulation have been researched mainly within the context of activities of the certain self-regulation organizations, their legal status and functions, interaction with power authorities, several means and tools of self-regulation.

The genesis of the establishment and development of legislation on self-regulation of professional appraising activities has been also presented.

Key words: Self-regulation, self-regulatory organizations (SRO), Land Evaluation, Land Management, Public Law, Private Law. 